\title{
RAPID SCREENING OF PHYTOPATHOGENIC Erwinia sp. OF TWO POTATO VARIETIES (SPUNTA AND DESIREE) FROM ALGERIAN AGRICULTURAL FIELDS
}

\author{
Slimane Mokrani ${ }^{1,2}$ \& El-hafid Nabti ${ }^{2}$ \\ ${ }^{1}$ Department of Agronomy, Laboratory of Research on Biological Systems and Geomantic (L.R.S.B.G.), \\ University of Mustapha Stambouli, Algeria \\ P.O. Box 305 Mascara 29000 \\ ${ }^{2}$ Laboratoire de Maitrise des Energies Renouvelables, Faculté des Sciences de la Nature et de la Vie, \\ Université de Bejaia, Algeria Bejaia 06000 \\ E-mail: nabtielhafid1977@yahoo.com; el-hafid.nabti@univ-bejaia.dz
}

Manuscript received: 21 May 2021. Revision accepted: 27 June 2021.

\begin{abstract}
Rapid screening of phytopathogenic Erwinia sp. of two potato varieties (Spunta and Desiree) from Algerian agricultural fileds. Isolation, phenotypic identification and in vitro phytopathogenicity screening of Erwinia sp. from agricultural field of two potato varieties (Spunta and Desiree) in Algeria. The current study aims to isolate, identify and screen phytopathogenic isolates of Erwinia sp. causing potato diseases. The techniques presented in this study for isolation and characterization of phytopathogenic Erwinia sp. are conventional methods that are used in this field of research. Seven phytopathogenic bacteria were recovered from potato tubers of two varieties (Spunta and Desiree). The phenotypic identification allowed characterizing typical colonies of Erwinia sp. on two semi-selective media: King's B and TCC media. Erwinia sp. formed characteristic colonies on King's B medium that were round, convex and representing creamy color. While, Erwinia sp. also developed specific colonies on TCC medium which were pale purple, circular, convex, even bulging; smooth and mucous. In vitro phytopathogenicity test on potato slices lead to screen the phytopathogenic isolate $\mathrm{E} 5$ characterized by highest rotten tissue zone of $(2.33 \pm 0.29 \mathrm{~cm})$ and $(2.33 \pm 0.58 \mathrm{~cm})$ toward Spunta and Desiree varieties, respectively. Followed, by isolate E4 characterized by rotten tissue zone of $(1.83 \pm 0.58 \mathrm{~cm})$ and $(2.17 \pm 0.29 \mathrm{~cm})$ toward Spunta and Desiree varieties, respectively; compared to their corresponding uninfected controls. The RTZ (Rotten tissue zone) evidently is proportional to the specific pathogenicity of Erwinia sp. isolates and the characteristic sensitivity of various varieties (Spunta and Desiree). Thus, make determining RTZ a rapid screening technique for the selection of the highest phytopathogenic isolates. This investigation provides valuable information for rapid screening (infected potato tuber) and characterization (isolation using semi-selective media) of pathogenic Erwinia sp. engendering potato disease compared to existing methods like infection of leaves or plants; and phytopathogenic Erwinia sp. identification through PCR amplification or in situ hybridation.
\end{abstract}

Key words: Desiree, Erwinia sp., phytopathogenicity, potato varieties, Spunta

\section{INTRODUCTION}

The characterization of plant diseases is undoubtedly of major importance. Especially when it comes to dealing with a redoubtable pathogen as Erwinia sp. or worldwide important crop like potato. The three main factors constituting this branch include bacteria/ plant pathogenicity mechanisms have received a great attention. Therefore, the study of these main factors could contribute directly to our understanding of all phenomena and interdependencies generated; and indirectly to the control and preservation of potato crops for a sustainable agriculture. Erwinia genus comprises species that are plant pathogens, non-pathogen, epiphytes, and opportunistic human pathogens (Borruso et al., 2017). Particularly, it consists of 15 species that are associated with plants as pathogens, saprophytes, or epiphytes (Lelliott \& Dickey, 1984). Mainly, species causing the highest losses of fruit or vegetables include Erwinia amylovora, E. carotovora subsp. atroseptica, E. carotovora subsp. carotovora, E. chrysanthemi and E. stewartii (Waleron et al., 2004). This genus is characterized by Gram-negative bacteria belonging to Enterobacteriacae family (Aremu \& Babalola, 2015). Erwinia and its subgeneric members usually are motile rods bearing peritrichous flagella and are able to ferment glucose leading to acid formations. Their fermentative pathway yields mixed acids and 2,3-butanediol. All are catalase positive and negative for exocellular cytochrome oxidase activity (Kado, 2006). Several 
species (soft rot Erwinia spp.) were moved to two new genera as Pectobacterium and Dickeya (Nabhan et al., 2013). Especially, pectinolytic Erwinia (E. carotovora subsp. atroseptica, E. carotovora subsp. carotovora and E. chrysanthemi) attacks potato plants (Ladjouzi, 2006).

Potato (Solanum tuberosum L.) is a perennial, herbaceous, dicotyledonous and a tuberous plant of the Solanaceae family (Boufares, 2012). It is cultivated in more than 150 countries and plays a key function in the world food system. Potato is ranked as the fourth most important crop in the world after rice, maize and wheat (Daoud \& Doudou, 2017). In 2013, world potato production was estimated at 368.1 million tonnes, with a cultivated area of 19.4 million hectares, characterized by an average yield production of 18.9 tonnes / hectare. This, without including seedlings that account for 32.2 million tonnes (FAOSTAT, 2015). China was first rankst among the producing countries reaching 88.9 million tonnes (FAOSTAT, 2015). The demand for potatoes is increasing thus representing the leading crop market in terms of surface area and production (Chehat, 2008). The two varieties (Spunta and Desiree) were selected to investigate in this study as indicator models of phytopathogenicity because their widespread cultivation in Algeria. In addition, the varieties was conducted to test the effect of cultivar variability on potato sensitivity toward bacterial diseases (Hamad et al., 2021). Indeed, there were 169 potato varieties registered in Algeria (Foudil, 2016). The varieties Spunta and Desiree were among the most cultivated. The Spunta variety was dominant; as more than $55 \%$ of the cultivated areas were composed of this variety (Kheddam et al., 2017).

Numerous bacterial infections are occurring on the tuber and crop of potato. The following genera include these bacteria: Ralstonia, Pectobacterium (Erwinia), Streptomyces and Clavibacter (Latour et al., 2008). Various species of Erwinia are known as potato pathogens such as Erwinia carotovora subsp. atroseptica (van Hall) Dye, Erwinia carotovora subsp. carotovora and Erwinia chrysanthemi (Pérombelon \& Kelman, 1980). All three bacteria can cause tuber soft rot; E. carotovora subsp. atroseptica is the primary blackleg agent in cool areas, whereas in hotter regions E. chrysanthemi predominates (Hélias et al., 2000b).

Bacterial pathogenic diseases is an important problem in potato production. Pathogenic bacteria may remain and spread in farming areas once introduced. In addition, its unintentional and unrecognized propagation are particularly essential in a contaminated or latent (asymptomatic) potato seed infection (Stevenson et al.,
2001). Bacterial phytopathogens proliferate quickly and cause significant loss and economic harm of production under favorable conditions for disease development (De La Fuente \& Burdman, 2011). In agricultural production, more consideration has been devoted to bacterial infections (Rienzie et al., 2021). It is challenging to control bacterial infections in potato farms. When a disease is transmitted to fields, it can survive and spread over lengthy period (Azhar \& Wani, 2021).

E. carotovora subsp. carotovora and Erwinia carotovora subsp. atroseptica are quality, pathogens causing losses in the field and during storage (Latour et al., 2008). Around $22 \%$ of potatoes are lost every year because of viral, bacterial, fungal and pestinal attacks on the tuber and potato plants, with over 65 million tons annually damaged, and $30-50 \%$ this enormous loss is caused alone by bacterial soft rot (Czajkowski et al., 2011). It is difficult to estimate, but known to be huge, loss of agricultural production owing to bacterial soft rot. In 1980, the worldwide loss of potato crop due to soft rot was expected to range from US\$50 to US\$100 million (Pérombelon \& Kelman, 1980). Blackleg, aerial stem rot, and stem wet rot are main bacterial foliar diseases caused by pectolytic erwinias, as well as bacterial soft rot in tubers (Van der Wolf \& De Boer, 2007). Probably, bacterial soft rot and blackleg, are the most severe crop diseases causing productivity loss (Salem \& Abd El-Shafea, 2018).

In numerous potato cultivars in western Algeria, soft rot symptoms were reported in potato plants (Benada et al., 2018). When potato resistance is compromised, bacteria tend to cause infections by acting as opportunistic agents. Tubers and stems are afflicted with these latent infection (Pérombelon \& van der Wolf, 2002; Raimi et al., 2017). The formation of a watersoaked zone on the tuber surrounding lenticels or eyes is the first symptom of soft rot. When one of these lesions was cut, it was noticed fragile the tissue (Koepsell, 1978). Soft rot symptoms of potato tubers are shown as watered lesions, which become gradually soft (mushy, disintegrated and discolored). The tissue becomes dark, creamy and slim in the infected lesions and finally decomposed (Rahman et al., 2012); plant emergence was reduced, plants were weak, curled and the leaves drooped, similar to wilt disease or water deficiency, and ultimately yellowing symptoms appeared (Rosenzweig et al., 2016). While, blackleg symptoms appeared when Erwinia predominated in decomposing mother tubers, penetrate the stems, and proliferate in xylem vessels under favorable climatic circumstances (Pérombelon \& van der Wolf, 2002). 


\section{MATERIALS AND METHODS}

Research Site. The study was carried out during April 2019. Characterizing symptomatic potato tubers belonging to two varieties: Spunta (white) and Desiree (red). Seven samples were collected from three fields at Sirat of the Mostaganem department. Figure 1 and Table 1 showed the geographical location of the three potato fields.

Collection of Potato Tubers. Potato tubers showing typical symptoms were chosen. The infected parts were characterized by creamy to dark brown, granular consistency, spongy appearance (Benada et al., 2018) and releasing characteristic disagreeable odor (Rosenzweig et al., 2016).

Isolation. Isolation of Erwinia sp. from infected tuber tissues was performed using the modified methods described by Pérombelon \& van der Wolf (2002) and Lacroix \& Vézina (2003). Briefly harvested potato tubers were washed to remove soil excess. Then, the tubers were cut longitudinally into two identical parts using a sterile blade. Samples of $1 \mathrm{~g}$ were taken from the unhealthy areas and were macerated in sterile mortar. A suspension was prepared in $0.9 \%$ of sterile physiological water with constant stirring for $30 \mathrm{~min}$. From this suspension, decimal serial dilutions were made $\left(10^{-1}, 10^{-2}, 10^{-3}, 10^{-4}, 10^{-5}\right.$ and $\left.10^{-6}\right)$. Bacteria were isolated on a semi-selective King's B medium. They were purified by successive transplantations on a modified CCT (Cycloheximide Crystal violet Thallium nitrate) medium.

Phenotypic Identification. Colonies presenting typical characteristics of Erwinia sp. formed on Petri dishes containing semi-selective King's B and CCT media were described for establishing their phenotypic aspects (Lacroix \& Vézina, 2003).

\section{Phytopathogenicity Test}

Preparation of Bacterial Inocula. Pre-culture of each bacterial isolate was prepared from a colony streaked

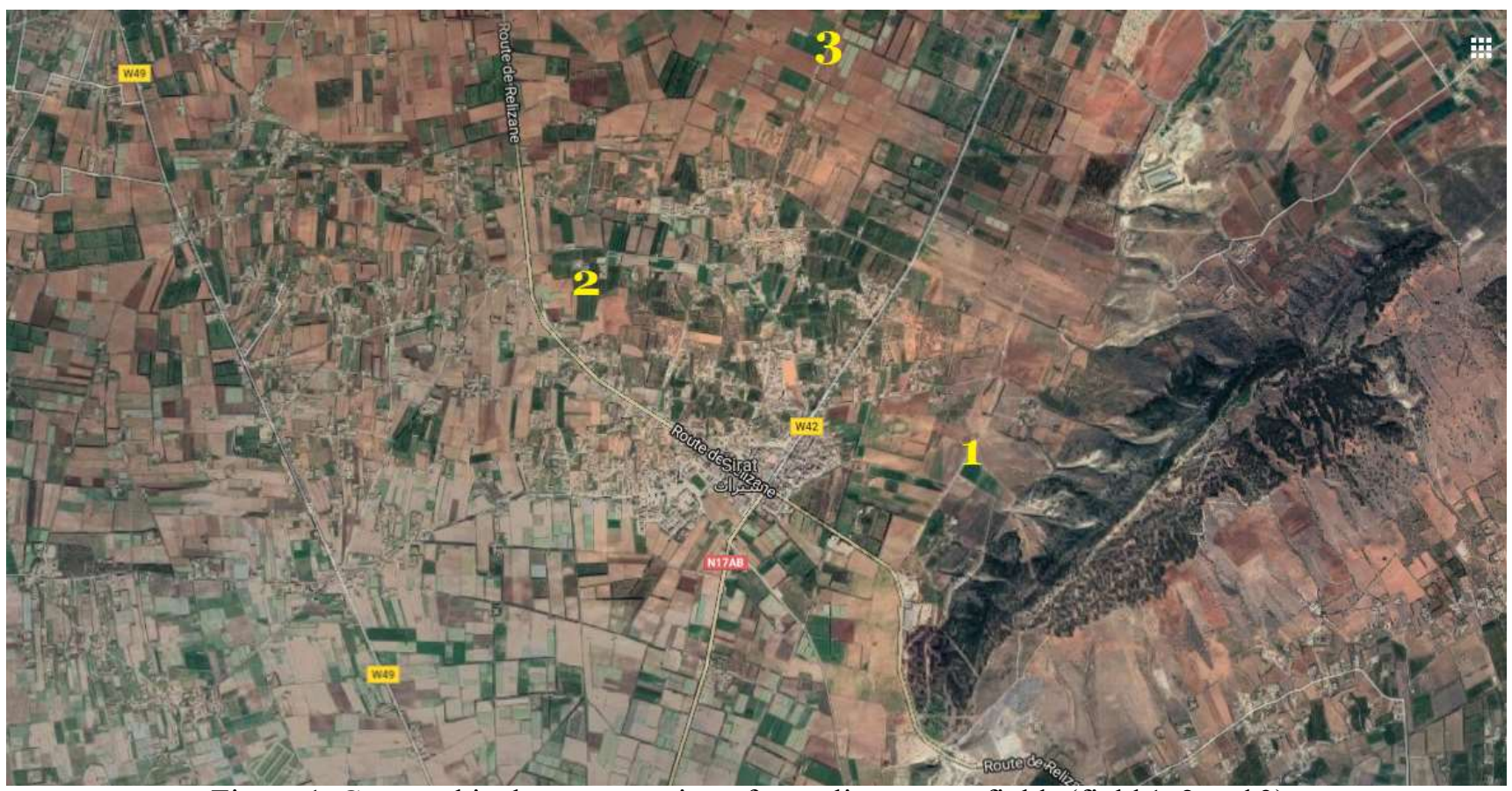

Figure 1. Geographical representation of sampling potato fields (field 1,2 and 3).

Table 1. Represents the GPS locations of potato fields

\begin{tabular}{ll}
\hline Fields & GPS location \\
\hline Field 1 & $35^{\circ} 46^{\prime} 49.8^{\prime \prime} \mathrm{N} 0^{\circ} 12^{\prime} 15.9^{\prime \prime} \mathrm{E}$ \\
Field 2 & $35^{\circ} 47^{\prime} 24.7^{\prime \prime} \mathrm{N} 0^{\circ} 10^{\prime} 37.4^{\prime \prime} \mathrm{E}$ \\
Field 3 & $35^{\circ} 48^{\prime} 17.0^{\prime \prime} \mathrm{N} 0^{\circ} 11^{\prime} 34.7^{\prime \prime} \mathrm{E}$ \\
\hline
\end{tabular}


on Petri plate containing King's B medium, followed by incubation at $30^{\circ} \mathrm{C}$ for $24 \mathrm{~h}$. These pre-cultures served to prepare bacterial suspensions in $5 \mathrm{~mL}$ of physiological sterile water (Hélias et al., 2000a). These last constituted the bacterial inocula used forming approximately $1.5 \times 10^{8}$ $\mathrm{CFU} / \mathrm{mL}$ equivalents to $0.5 \mathrm{McF}$ arland standard (Hajimehdipoor et al., 2010). The McFarland method was designed to estimate bacterial concentrations by means of a turbidity scale (absorbance) which consists of a series of tubes previously calibrated, and with an optical density produced by the precipitation of barium sulphate. This absorbance is compared to bacterial suspensions (Eduardo et al., 2018).

Preparation of Plant Material and Inoculation. To verify the phytopathogenicity of the bacterial isolates in in vitro trials, potato slices were infected according to the modified method described by Priou \& Jouan (1996). Potato tubers were washed before hand and soaked in ethanol (10\%) for $5 \mathrm{~min}$. Then, rinsed with sterile water and dried. Each tuber was cut longitudinally into several identical slices and placed in Petri dishes containing sterile filter paper. Wells $(5 \times 5 \mathrm{~mm})$ were made in the centers of the potato slices. Then, they were filled with $50 \mu \mathrm{L}$ of each bacterial inoculum. Petri dishes containing infected slices were incubated at $30{ }^{\circ} \mathrm{C}$ for $48-72 \mathrm{~h}$. Development of typical symptoms were monitored visually and the phytopathogenicity of isolates were estimated through measurement the rotten tissue zone (RTZ) formed on potato slices (in $\mathrm{cm}$ ).

Statistical Analysis. To establish the significance of phytopathogenicity results of Erwinia sp. isolates toward the two potato varieties (Spunta and Desiree), data were analyzed by one-way ANOVA, followed by Dunnett test compared to their corresponding controls. Results were considered statistically significant at $(\mathrm{p}<0.001)$ and $(\mathrm{p}<0.005)$. Then, for determining if the phytopathogenicity result differences of Erwinia sp. isolates between the two varieties were significant, the data were exanimated by two-way ANOVA, followed by Sidak's multiple comparison tests. Results were considered statistically significant at $(\mathrm{p}<0.05)$ and $(p<0.01)$. Experiments were performed in triplicate and repeated three times with similar results. All results were statistically compared using Graph Pad Prism V. 6.0 .

\section{RESULTS AND DISCUSSION}

Phenotypic Identification on King's B Medium. A total of 7 Erwinia isolates (E1, E2, E3, E4, E5, E6 and E7) were recovered from all samples of infected potato tubers. After incubation at $30^{\circ} \mathrm{C}$ for $24 \mathrm{~h}$ on King's B medium, characteristic colonies of Erwinia sp. were identified round, convex and representing creamy color (Figure 2). Lakhdar (2018) reported that Erwinia genus formed round, convex, creamy colonies on King's B medium.

Phenotypic Identification on CCT Medium. After incubation on CCT medium at $30^{\circ} \mathrm{C}$ for 48 , phenotypic aspect of Erwinia sp. isolates revealed typical colonies that were pale purple, circular, convex, even bulging; smooth and mucous. Their growth was slower than King's B medium (Figure 3).

Phytopathogenicity Test. After three days of inoculation, characteristic symptoms were observed on tubers of the two potato varieties (Spunta and Desiree). They were small water-soaked spots on the surface. Rapidly these spots enlarged and the vegetal tissue was decomposed. The soft and blister-like areas were formed on the surface. Black rot lesion spread on rotting

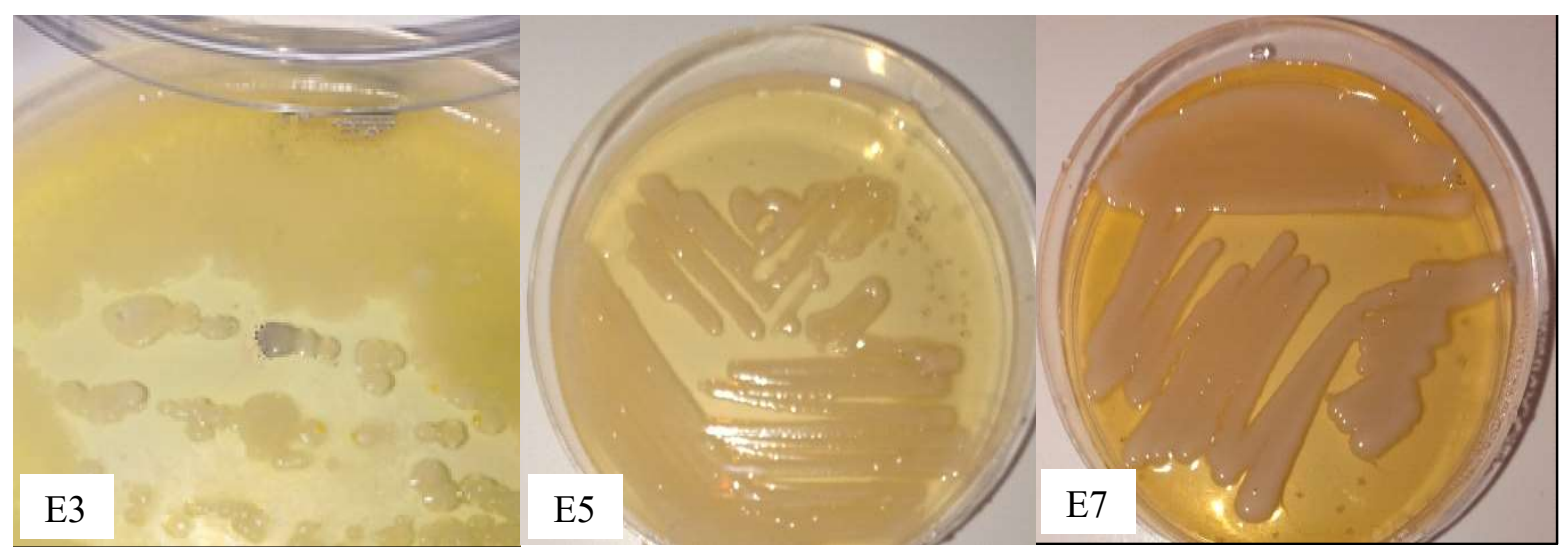

Figure 2. Macroscopic aspect of Erwinia sp. isolates on King's B medium. 
tuber for some isolates, including isolate E7 on Sunta and Desiree varieties, and isolate E3 on Spunta variety (Figure 4). Similar results were reported by Elhalag et al. (2020) that the most frequently observed symptoms of collected potato tubers samples were slimy, wet, black rot lesion spreading on rotting tuber. Tuber tissues were distinctly macerated to a creamy consistence with a blacked color appearance.

All symptomatic samples were belonging to $\mathrm{cv}$. Scotch Hermes and cv. Scotch Cara and may indicate the susceptibility of the reported cultivar for soft rot and/ or blackleg infection. Furthermore, the results of this current study highlight a concordance to results were reported by Marković et al. (2021) stated that two types of tissue decomposition could be notified for these diseases: the first group of isolates (Like E3, E4 and E7 for Spunta variety, and E4 and E7 for Desiree variety) produced cream-colored rotting tissue with dark brown margins in the zone between the healthy and decomposed tissue, and the second group (Such as isolates E5 for Spunta variety, and E3 and E5 for Desiree variety) devastated the tissue causing cream-colored rotting but with no visible margins.

Measurement of necrotic area lengths showed sensitivity of the two potato varieties (Spunta and Desireee) to Erwinia sp. isolates (Figure 5). Higher susceptibility of Spunta was detected compared to Desiree. Phytopathogenic screening leaded to the selection of isolate E5 characterized by diameter of $(2.33 \pm 0.29 \mathrm{~cm})$ and $(2.33 \pm 0.58 \mathrm{~cm})$, followed by isolate $\mathrm{E} 4$ characterized by diameters of $(1.83 \pm 0.58$ $\mathrm{cm})$ and $(2.17 \pm 0.29 \mathrm{~cm})$ Spunta and Desiree varieties, respectively.

The phytopathogenicity test is based on the observation of different symptoms caused after infection of potato tubers, in order to determine the level of pathogenicity of different pectinolytic strains as well as the sensitivity degree of various varieties (Ibrahim et al., 1978; Priou \& Jouan, 1992; Aiteche \& Benzid, 2018). Rotten tissue diameters can vary up to 11 -fold between the highest and the lowest pathogenic strains indicating clearly the variability of pathogenicity between tested strains. This variability, especially in the
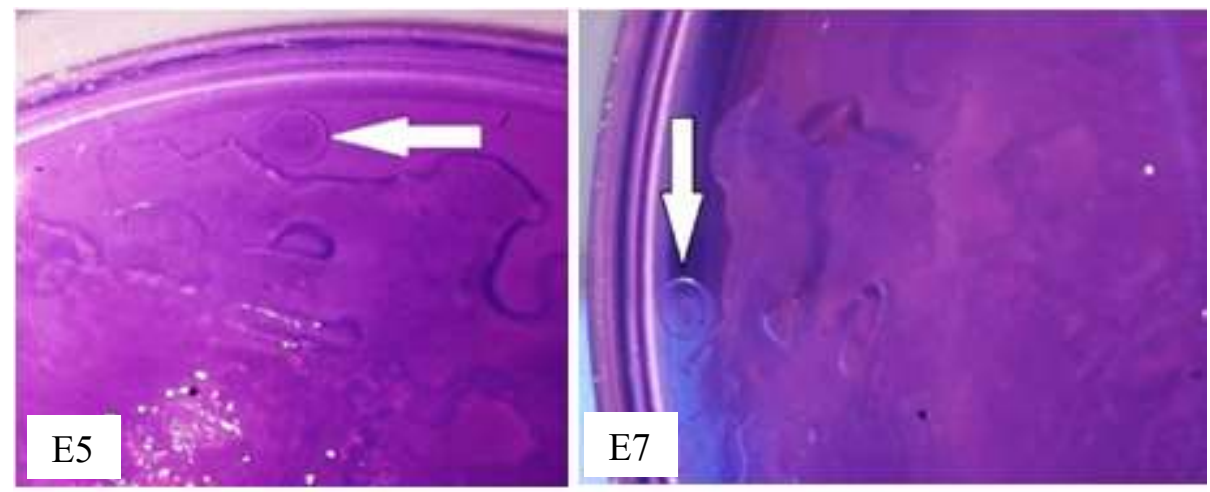

Figure 3. Macroscopic aspect of Erwinia sp. isolates on CCT medium (Arrows indicate the colony aspects of isolates E5 and E7).
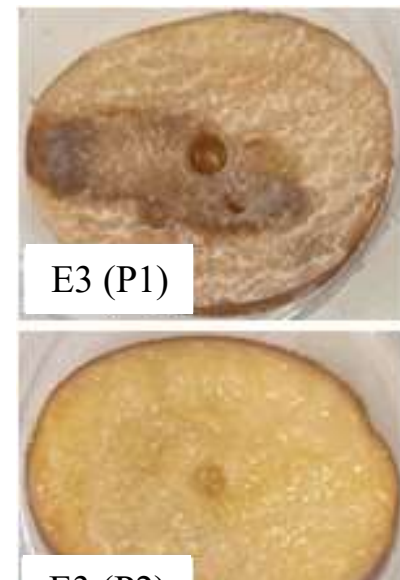

E3 (P2)
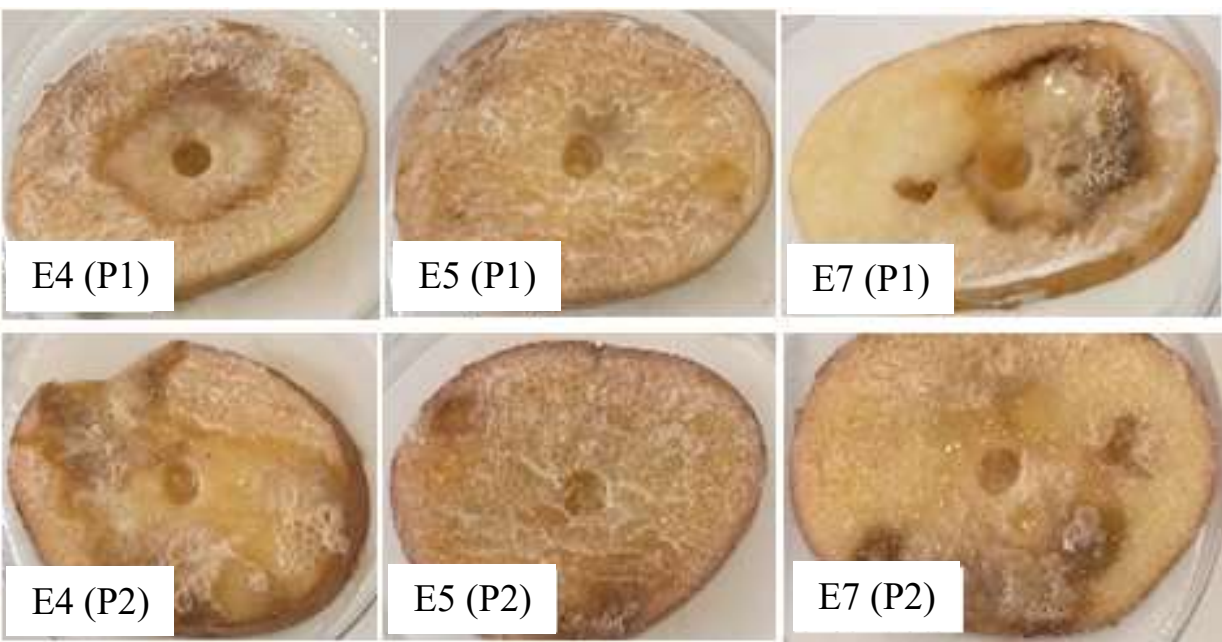

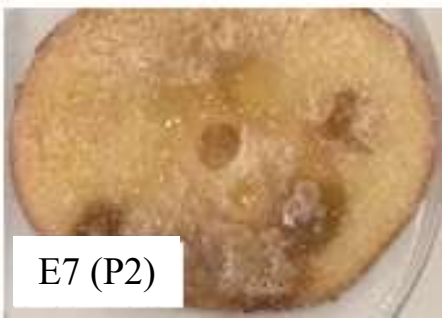

Figure 4. Pathogenicity test of Erwinia sp. isolates on potato varieties (P1: Spunta, P2: Desiree, E: Erwinia sp). 
E. carotovorum species, has been described by many investigations (Priou \& Jouan, 1992; Yahiaoui-Zaidi et al., 2003).

The white variety (Spunta) was more sensitive than the red variety (Desiree). This low tolerance could be explained by the Spunta variety deficiency in the synthesis of a nuomber of secondary compounds such as glycolakaloids ( -solanine and -chaconine) compared to Desiree variety. Indeed, these secondary metabolites are involved and play a significant role in the resistance against various pathogens and pests (Ginzberg et al., 2009). In addition, Andrivon et al. (2003) mentioned also that the resistance of potato varieties to soft rot agents was correlated to their content of phenolic compounds and other bioactive substances.

Comparison of the phytopathogenicity results between the two varieties by two-way ANOVA followed by Sidak's multiple comparison tests revealed significant differences among two isolates (E2 and E3) (Table 2). This mean that globally phytopathogenicity of Erwinia sp. depended on potato variety and Erwinia sp. isolates.

Characterization of phytopathogenic bacteria infecting potato fields, especially Erwinia sp., seemed to be of a great importance for a better understanding of different aspects related to the plant pathogenicity phenomenon. Phenotypic identification of bacterial isolates revealed characteristic colonies of Erwinia sp. on King's B and CCT media. They were round, convex and creamy-white on King's B medium and pale purple, circular, convex, even bulging; smooth and mucous on CCT medium. Colony morphology for Erwinia spp. varies depending on the type of media on which they are cultivated. In general, the colonies were white and smooth. They may be domed, shining, mucoid-type colonies with radial striations or may appear smooth with

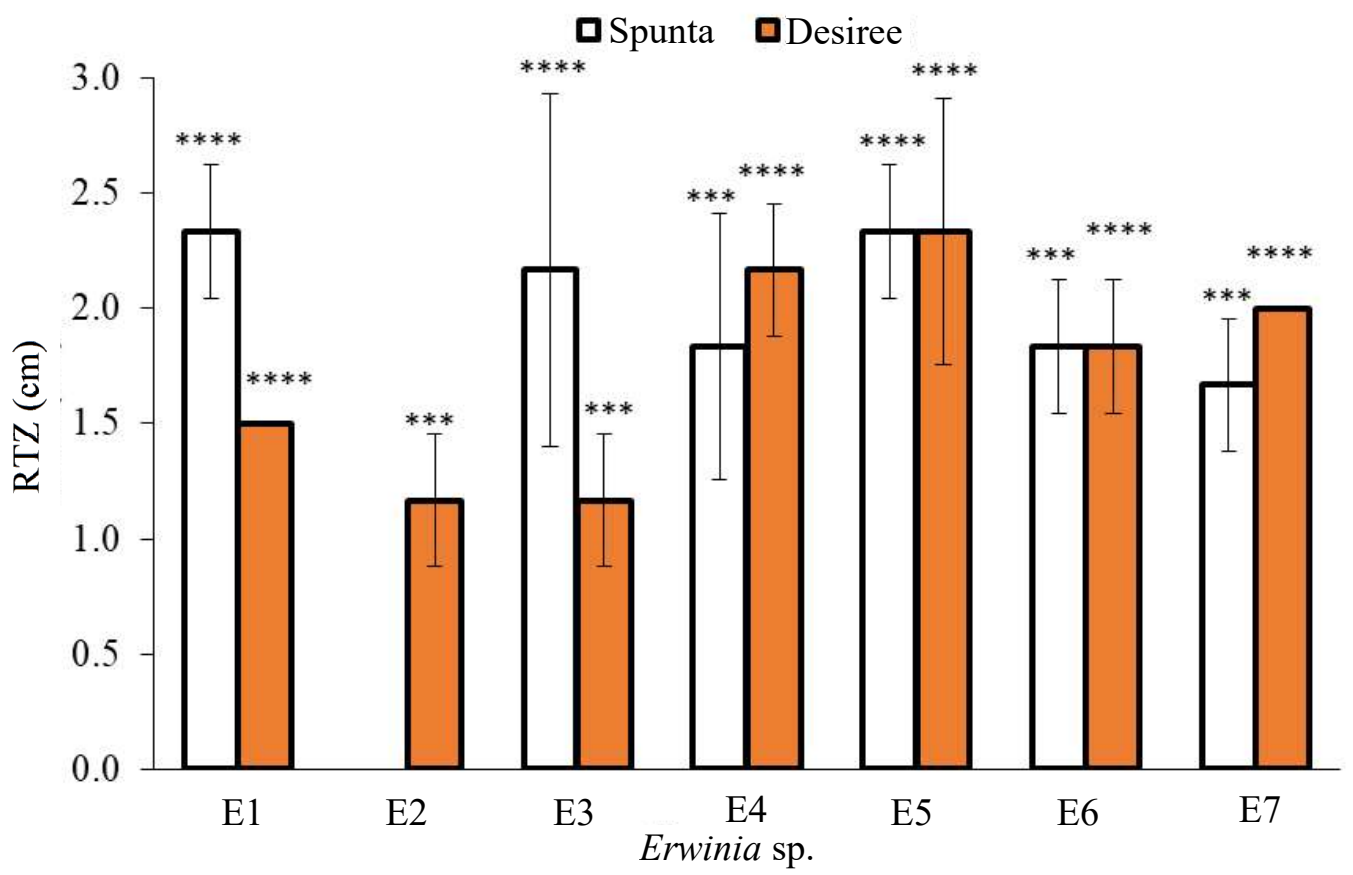

Figure 5. Phytopathogenicity test of Ewinia sp. isolates against two potato varieties (RTZ: rotten tissue zone; ****: significant difference at $\mathrm{p}<0.001 ; * * *$ : significant difference at $\mathrm{p}<0.005)$.

Table 2. Two-way ANOVA followed by Sidak's multiple comparison test

\begin{tabular}{ccc}
\hline Isolates & Adjusted P value & Summary \\
\hline E1 & 0.0687 & $\mathrm{~ns}$ \\
E2 & 0.0042 & $* *$ \\
E3 & 0.0179 & $*$ \\
E4 & 0.899 & $\mathrm{~ns}$ \\
E5 & $>0.9999$ & $\mathrm{~ns}$ \\
E6 & $>0.9999$ & $\mathrm{~ns}$ \\
E7 & 0.899 & $\mathrm{~ns}$ \\
\hline
\end{tabular}

ns $=$ not significant $; *=$ significant difference at $\mathrm{p}<0.05 ;(* *)$ significant difference at $\mathrm{p}<0.01$. 
entire edges. Craters may be formed around the colonies on some media. Also, pigments can be produced by a number of species; ranging from cream, pale yellow to light pink (Holt et al., 1986).

After $48 \mathrm{~h}$ of incubation on King's B medium, macroscopic characterization of $E$. carotova colonies showed characteristic small, whitish, domed and mucous colonies (Benada, 2019). Moreover, after $72 \mathrm{~h}$ of incubation on CCT agar, colonies of E. amylovora were pale purple, circular, strongly convex or even domed, then become smooth and mucous (LNPV, 2005; CIPV, 2016). Some Erwinia species are complex taxons, composed of strains having a wide variety of phenotypic, biochemical, environmental and genetic characteristics (Toth et al., 2003; Yap et al., 2004).

In vitro phytopathogenicity test revealed high sensitivity (RTZ $>10 \mathrm{~mm}$ ) of the two potato varieties (Spunta and Desireee) to Erwinia sp. isolates according to categorizing symptom scale proposed by Pédron et al. (2021). Rotten tissue zone can be attributed to the secretion by Erwinia sp. isolates of secondary metabolites acting as phytopathogenicity factors and damaging potato plant tissue. Mainly, pectinolytic Erwinia caused typical symptoms of blackleg or tuber soft rot secreted effective cell wall degrading enzymes responsible for tissue maceration (Pritchard et al., 2012). It was obvious that RTZ would have a proportional relationship with the specific pathogenicity of Erwinia sp. isolates, and also proportional to the characteristic sensitivities of different varieties (Sunta and Desiree). Thus, if the pathogenicity of Erwinia sp. isolates or the sensitivity of potato variety increases, the RTZ will also increases.

A higher susceptibility to Spunta was compared to Desiree. Similar results were reported by Benada (2019) reported that the Desiree variety was the most resistant to E. carotova subsp. carotova among six potato varieties (Spunta, Kondor, Desiree, Laura and Margaritte). At temperatures $15-25^{\circ} \mathrm{C}$, the Spunta variety produced high quantities of pectinases, notably endopolygalacturonic transaminase, thus induced more symptoms (Pérombelon, 1994; Smadja et al., 2004). This finding was also confirmed by the study reported by Rabot et al. (1994) which described 8 potato cultivars, among Desiree variety was moderately susceptible to soft rot caused by $P$. atrosepticum strains. This investigation had additionally shown that this variety had also a low susceptibility to blackleg disease. In another study, Allefs et al. (1996) showed that cultivar Desiree was the most susceptible among 12 potato varieties. Moreover, evaluation of the response of 14 potato cultivars to four potato diseases leads to conclude that the Desiree cultivar was the most susceptible to dry rot (Acuña et al., 2004). Furthermore, the aggressiveness of E. carotova susp. carotova was confirmed in different potato varieties (Spunta, Kondor, Desiree, Laura and Margaritte) that showed significant differences between strains of the same variety and different varieties. The variation between strain virulence and variety susceptibility was significant $(\mathrm{p}<0.05)$. Particularly, among 20 Erwinia isolates tested, the strain MAI was highly virulent on the Spunta variety compared to the other strains (Benada, 2019).

There were few studies focused on phytopathogenicity of Erwinia spp. in western Algeria. Plant pathogenic prokaryotes, like other plant pathogens, are influenced by a variety of factors, including local climate, host plant distribution, pathogen dispersal ability, occurrence of animal vectors, pathogen adaptability to local conditions, pathogen capacity to infect new host plants, and local cultivar resistance (Kudela, 2009). E. carotovora was becoming a concern because of the environmental conditions in the eastern areas of Algeria. Therefore, temperature and the availability of water are two major influences on bacterial infection development. Structural and physiological modifications increased incidence and severity of diseases that can be a consequence of these variables when temperature and relative humidity are highest. Statistical analysis demonstrated a substantial impact of various factors on Erwinia spp. population dynamics and soft rot development on the surface of wounded potato tubers including temperature $\left(10,15\right.$ and $\left.20^{\circ} \mathrm{C}\right)$, relative humidity $(86,96$ and $100 \%)$ and initial bacterial inoculum $\left(10^{5}, 10^{7}\right.$ and $10^{9} \mathrm{CFU} / \mathrm{mL}$ ) (Moh et al., 2012).

Bacterial strains can considerably influence the in vitro pathogenicity test. Various Erwinia isolates displayed typical signs of soft red with varied degrees of aggression in treated potato tubers (Elhalag et al., 2020). Erwinia isolates with high levels of extracellular plant cell wall-degrading enzyme synthesis were highly effective in infecting potatoes (Pérombelon \& Kelman, 1980). The lack of E. carotovora subsp. carotovora pathogenicity in potato cv Bintje and Desiree cultivars might be attributed to its deficiency to generate an amplification product using primers ( $\mathrm{Y} 1$ and $\mathrm{Y} 1$ ) (Yahiaoui et al., 2003). Therefore, there was an urgent need to combine phenotypic identification on selective media, and specific and sensitive polymerase chain reaction (PCR) assay for the rapid, accurate detection of Erwinia spp. symptomatic potato tuber/plant samples in western Algeria. 


\section{CONCLUSION}

Bacterial infections caused by Erwinia species are probably among the most spreader potato diseases. This current study has described a simple method for isolation and identification of these bacteria from two potato varieties (Spunta and Desiree) using phenotypic characterization on two semi-selective media (King's $\mathrm{B}$ and TCC). Moreover, a rapid screening technique of phytopathogenic isolates through reproducing symptom on potato slices was reproduced in in vitro trials that allowed comparison and determination of the highest phytopathogenic isolates. The RTZ (Rotten tissue zone) seemed to be proportional to the specific pathogenicity of Erwinia sp. isolate, and the characteristic sensitivity of various varieties (Sunta and Desiree). Thus, as the pathogenicity of Erwinia sp. isolate or the sensitivity of potato variety increases, the RTZ will increases. The techniques presented in this study for isolation, identification and characterization of phytopathogenic Erwinia genus were conventional methods used in this field of research. The rapid isolation and characterization of phytopathogenic Erwinia sp. isolates by colorometric method using new selective media seemed to be very promising, especially for the differentiation between Erwinia species. Also, more advanced techniques exist, such as in situ hybridization and PCR amplification. Studies and inventories of phytopathogenic bacteria featured a great importance, allowing to butter understanding of different aspects related to the phytopathogenicity such as pathogens distribution, diagnosis, and the phytopathogenicity evolution.

\section{ACKNOWLEDGMENTS}

We deeply thank the team of the Journal "Jurnal Hama dan Penyakit Tumbuhan Tropika" who helped us in the correction of the manuscript. We fully recognize their valuable help in the finalization of this article.

\section{REFERENCES}

Acuña I, Mancilla S, Sagredo B, Gutiérrez M, Vargas M, \& Delgado J. 2004. Identificación taxonó mica de las especies Fusarium causantes de pudricion seca en tuberculos de papa en el sur de Chile. In: $55^{\circ}$ Congreso Agrónomico de Chile, $5^{\circ}$ Congreso, Sociedad Chilena de Fruticultura, 1er Congreso Sociedad Chilena de Horticultura.Valdivia, $X^{a}$ Región-Chile. 19 al 22 de Octubre de 2004.
Aiteche H \& Benzid K. 2018. Activité antagoniste de la souche Trichoderma asperellum (T34) sur demi-tubercules de pomme de terre infectés par Dickeya solani. Mémoire de Master, Université de Béjaia.

Allefs JJHM, Van Dooijeweert W, Prummel W, Keizer LCP, \& Hoogendoorn J. 1996. Components of partial resistance to potato blackleg caused by pectolytic Erwinia carotovora subsp. atroseptica and E. chrysanthemi. Plant Pathol. 45(3): $486-496$.

Andrivon D, Corbière R, Lucas JM, Pasco C, Gravoueille JM, Pellé R, Dantec JP, \& Ellissèche D. 2003. Resistance to late blight and soft rot in six potato progenies and glycoalkaloid contents in the tubers. Am. J. Pot. Res. 80(2): 125-134.

Aremu BR \& Babalola OO. 2015. Classification and taxonomy of vegetable macergens. Front Microbiol. 6: 1361.

Azhar M \& Wani S. 2021. Wild Germplasm for Genetic Improvement in Crop Plants. Academic Press, London.

Benada M, Boumaaza B, Boudalia S, Khaladi O, \& Guessas B. 2018. Variability of aggressiveness and virulence of Erwinia carotovora subsp. carotovorum causing the soft rot on potato tubers in the western of Algeria. Int. J. Plant Biol. 9(1): $52-56$.

Benada M. 2019. Caractérisation phénotypique et génotypique d'Ewinia sp. pathogène et essaie de lutte biologique. Thèse. Université Oran 1. Oran.

Borruso L, Salomone-Stagni M, Polsinelli I, Schmitt AO, \& Benini S. 2017. Conservation of Erwinia amylovora pathogenicity-relevant genes among Erwinia genomes. Arch. Microbiol. 199(10): 1335-1344.

Boufares K. 2012. Comportement de trois variétés de pommes de terre (Spunta, Désirée et Chubak) entre deux milieux de culture substrat et hydroponique. Thèse de Magistère en Agronomie. Université Aboubekr Belkaid. Tlemcen.

Chehat F. 2008. La filière pomme de terre algérienne, une situation précaire, Journée d'étude sur la filière pomme de terre, situation actuelle et perspectives. E.N.S.A, El-Harrach. 18 Juin 2008. pp.1-13. 
CIPV. 2016. NIMP 27: Protocoles de diagnostic pour les organismes nuisibles réglementés. PD 13: Erwinia amylovora. https://www.ippc.int/static/ media/files/publication/fr/2017/02/ DP_13_2016_Fr_2017-01-11.pdf. Accessed on 17 June 2021.

Czajkowski R, Pérombelon MCM, van Veen JA, \& van der Wolf JM. 2011. Control of blackleg and tuber soft rot of potato caused by Pectobacterium and Dickeya species: a review. Plant Pathol. 60(6): 999-1013.

Daoud H \& Doudou O. 2017. Etude comparative de 14 variétés de pomme de terre cultivée (Solanum tuberosum L.) dans la région de Mostaganem. Mémoire de Master en Agronomie. Université Abdelhamid Ibn Badis, Mostaganem.

De La Fuente L \& Burdman S. 2011. Pathogenic and beneficial plant associated bacteria. In: Lal R (Ed.). Agricultural Science. EOLSS Publishers, Oxford.

Eduardo LG, Ramirez BS, Maribel CF, Pescador MGN, \& Cruz FJM. 2018. Low accuracy of the McFarland method for estimation of bacterial populations. Afr. J. Microbiol. Res. 12(31): 736740 .

Elhalag K, Elbadry N, Farag S, Hagag M, \& Hussien A. 2020. Etiology of potato soft rot and blackleg diseases complex in Egypt. J. Plant Dis. Prot. 127: 855-871.

FAOSTAT. 2015. Food and Agriculture Organization of the United Nations. Produit par pays. Available via. http://www.fao.org/faostat/en/ \#home. Accessed on 17 June 2021.

Foudil FZ. 2016. La première variété de pomme de terre algérienne portera le nom de Omnia. https:// www.elwatan.com/pages-hebdo/etudiant/lapremiere-variete-de-pomme-de-terre-algerienneportera-le-nom-de-omnia-16-03-2016. Accessed on 16 June 2021.

Ginzberg I, Tokuhisa JG, \& Veilleux RE. 2009. Potato steroidal glycoalkaloids: biosynthesis and genetic manipulation. Potato Res. 52(1): 1-15.

Hajimehdipoor H, Samadi N, Mozaffarian V, Rahimifard N, Shoeibi S, \& Pirali HM. 2010. Chemical composition and antimicrobial activity of Oliveria decumbens volatile oil from west of Iran. J. Med. Plants. 9(6): 39-44.
Hamad Y, Shaaban WI, Youssef SAG, \& Balabel NM. 2021. Varietal differences and their relation to brown rot disease resistance in potato. In: Awaad H, Abu-hashim M, \& Negm A(Eds.). Mitigating Environmental Stresses for Agricultural Sustainability in Egypt. pp. 251-269. Springer Nature, Switzerland.

Hélias V, Andrivon D, \& Jouan B. 2000a. Development of symptoms caused by Erwinia carotovora ssp. atroseptica under field conditions and their effects on the yield of individual potato plants. Plant Pathol. 49(1): 23-32.

Hélias V, Andrivon D, \& Jouan B. 2000b. Internal colonization pathways of potato plants by Erwinia carotovor ssp. atroseptica. Plant Pathol. 49(1): $33-42$.

Holt JG, Bergey DH, \& Krieg NR. 1986. Bergey's Manual of Systematic Bacteriology, Vol. 1 \& 2. Williams \& Wilkins, Baltimore.

Ibrahim M, Jouan, B, Samson R, Poutier F, \& Saily M 1978. Prospect of a pathogenicity test concerning Erwinia carotovora var. atroseptica and Erwinia carotovora var. carotovora on half potato tubers, variation according to variety of bacterial species and stains, inoculums dose, temperature, variety of potatoes, physiological age of tubers and delay between injury and inoculation. Proceeding 4th International Plant Conference plant pathogenic Bacteria. pp. 591-602. Angers-França: INRA, Angers. France.

Kado CI. 2006. Erwinia and related genera. In: Dworkin M, Falkow S, Rosenberg E, Schleifer KH, Stackebrandt E (Eds.). The Prokaryotes. pp. 443-450. Springer, New York.

Kheddam H, Allal-Benfekih L, Bendifallah L, \& Moudoud R. 2017. Effet de la variation climatique des zones de production sur le comportement et le rendement de variétés introduites de pomme de terre en Algérie. Agrobiologia. 7(2): 635643.

Koepsell PA. 1978. Controlling bacterial soft rot and blackleg of potatoes. https:// ir.library.oregonstate.edu/downloads/db78tc24x. Accessed on November 2020.

Kudela V. 2009. Potential impact of climate change on geographic distribution of plant pathogenic bacteria in central Europe. Plant Prot. Sci. 45: S27-S32. 
Ladjouzi R. 2006. Recherche et identification des Pectobacterium, agents de la pourriture molle sur différentes plantes hôtes: pommes de terre, tomates et carottes. Mémoire de Magister. Université Abderrahmane Mira. Béjaia.

Lacroix C \& Vézina L. 2003. Technique de laboratoire pour le diagnostic des bactéries phytopathogène. Laboratoire de diagnostic en phytoprotection pour la détection et l'identification des bactéries phytopathogènes. Mémoire DEA . Université de Rennes I. Rennes.

Lakhdar F. 2018. Contribution à l'étude des potentialités antiproliférative et antibactérienne des algues brunes et rouges de la côte d'El Jadida pour une valorisation médicale et environnementale. Thése. Université de Nantes. Nantes.

Latour X, Faure D, Diallo S, Cirou A, Smadja B, Dessaux Y, \& Orange N. 2008. Lutte contre les maladies bactériennes de la pomme de terre dues aux Pectobacterium spp. (Erwinia carotovora). Cah. Agric. 17(4): 355-360.

Lelliott RA \& Dickey R. 1984. Genus VII. Erwinia. In: Krieg NR \& Holt JG (Eds.). Bergey's Manual of Systematic Bacteriology, Vol. 1. pp. 469-476. The Williams \& Wilkins Co, Baltimore.

LNPV. 2005. Mise en évidence d' Erwinia amylovora à partir de végétal symptomatique par isolement et identification de la souche. Laboratorie National de la Protection des Végétaux, Unité Bactériologie.

Marković S, Stanković S, Jelušić A, Ilicić R, Kosovac A, Poštić D, \& Popović T. 2021. Occurrence and identification of Pectobacterium carotovorum subsp. brasiliensis and Dickeya dianthicola causing blackleg in some potato fields in Serbia. Plant Dis. 105(4): 1080-1090.

Moh AA, Massart S, Jijakli MH, \& Lepoivre P. 2012. Models to predict the combined effects of temperature and relative humidity on Pectobacterium atrosepticum and Pectobacterium carotovorum subsp. carotovorum population density and soft rot disease development at the surface of wounded potato tubers. J. Plant Pathol. 94(1): 181-191.

Nabhan S, De Boer SH, Maiss E, \& Wydra K. 2013. Pectobacterium aroidearum sp. nov., a soft rot pathogen with preference for monocotyledonous plants. Int. J. Syst. Evol. Microbiol. 63(7): 25202525.

Pédron J, Schaerer S, Kellenberger I, \& Van Gijsegem F. 2021. Early emergence of Dickeya solani revealed by analysis of Dickeya diversity of potato blackleg and soft rot causing pathogens in Switzerland. Microorganisms. 9(6): 1187.

Pérombelon MCM \& Kelman A. 1980. Ecology of the soft rot erwinias. Ann. Rev. Phytopathol. 18: 361-387.

Pérombelon MCM. 1994. Diversity in erwinias as plant pathogens. In: Lemattre M, Freigoun, S, Rudolph K, \& Swings JG (Eds.). Plant Pathogenic Bacteria. pp. 113-128. Versailles, France. Les Colloques 66, INRA-ORSTOM, Paris.

Pérombelon MCM \& van der Wolf JM. 2002. Methods for the detection and quantification of Erwinia carotovora subsp. atroseptica (Pectobacterium carotovorum subsp. atrosepticum) on potatoes: A laboratory manual. Scottish Crop Research Institute, Scotland.

Priou S \& Jouan B. 1992. Comparison of the effectiveness of two methods of screening potato to solf rot induced by Erwinia carotovora ssp. atroseptica. Proceeding of the joint conference of the EAPR breeding and varietal assessment section and the EUCARPIA potato section. pp. 139-140. Landerneau, France.

Priou S \& Jouan B. 1996. Les maladies provoquées par les bactéries pathogènes du genre Erwinia. In: Rousselle P, Robert Y, \& Crosnier JC (Eds.). Mieux Comprendre La Pomme de Terre. pp. 260-265. INRA Editions, Paris.

Pritchard L, Humphris S, Saddler GS, Parkinson NM, Bertrand V, Elphinstone JG, \& Toth IK. 2012. Detection of phytopathogens of the genus Dickeya using a PCR primer prediction pipeline for draft bacterial genome sequences. Plant Pathol. 62(3): 587-596.

Rahman MM, Ali ME, Khan AA, Hashim U, Akanda AM, \& Hakim MA. 2012. Characterization and identification of soft rot bacterial pathogens in Bangladeshi potatoes. Afr. J. Microbiol Res. 6(7): 1437-1445.

Raimi A, Adeleke R, \& Roopnarain A. 2017. Soil fertility challenges and biofertiliser as a viable alternative 
for increasing smallholder farmer crop productivity in sub-Saharan Africa. Cogent Food Agric. 3(1): 1400933.

Rabot B, Pasco C, \& Schmidt J. 1994. Assessing six Austrian potato cultivars for resistance to Erwinia carotovora subsp. atroseptica. Potato Res. 37(2): 197-203.

Rienzie R, Sendanayake L, De Costa D, Hossain A, Brestic M, Skalicky M, Vachova P, \& Adassooriya NM. 2021. Assessing the carboxymethylcellulose copper-montmorillonite nanocomposite for controlling the infection of Erwinia carotovora in potato (Solanum tuberosum L.). Nanomaterials. 11(3): 802.

Rosenzweig N, Steere L, Hammerschmidt R, \& Kirk W. 2016. Tuber soft rot, blackleg and aerial stem rot. Extension Bulletin E-3335: 1-4.

Salem EA \& Abd El-Shafea YM. 2018. Biological control of potato soft rot caused by Erwinia carotovora subsp. carotovora. Egypt J. Biol. Pest Control. 28: 94.

Smadja B, Latour X, Trigui S, Burini JF, Chevalier S, \& Orange N. 2004. Thermodependence of growth and enzymatic activities implicated in pathogenicity of two Erwinia carotovora subspecies (Pectobacterium spp.). Can. J. Microbiol. 50(1): 19-27.
Stevenson WR, Loria R, Franc GD, \& Weingartner DP. 2001. Compendium of Potato Diseases. The American Phytopathological Society. Saint Paul, Minnesota.

Toth IK, Bell KS, Holeva MC, \& Birch PRJ. 2003. Soft rot erwiniae: from genes to genomes. Mol. Plant Pathol. 4(1): 17-30.

van der Wolf JM \& De Boer SH. 2007. Bacterial pathogens of potato. In: Vreugdenhil D, Bradshaw J, Gebhardt C, Govers F, Taylor M, MacKerron $\mathrm{D}$, \& Ross H (Eds.). Potato biology and biotechnology: Advances and Perspectives. 1st edition. pp. 595-617. Elsevier Delft, Netherlands.

Waleron M, Waleron K, \& Lojkowska E. 2004. Characteristics, identification, differentiation and taxonomy of plant pathogenic bacteria from the genus Erwinia. Postepy. Mikrobiolii. 43(3): 297319.

Yahiaoui-Zaidi R, Jouan B, \& Andrivon D. 2003. Biochemical and molecular diversity among Erwinia isolates from potato in Algeria. Plant Pathol. 52(1): 28-40.

Yap MN, Barak JD, \& Charkowski AO. 2004. Genomic diversity of Erwinia carotovora subsp. carotovora and its correlation with virulence. Appl. Environ. Microbiol. 70(5): 3013-3023. 